$1-1-2020$

\title{
All the Border's a Stage: Humanitarian Aid as Expressive Dissent
}

Jason A. Cade

Associate Dean for Clinical Programs and Experiential Learning, J. Alton Hosch Associate Professor of Law \& Community Health Law Partnership Clinic Director University of Georgia School of Law, cadej@uga.edu

P

\section{Repository Citation}

Jason A. Cade, All the Border's a Stage: Humanitarian Aid as Expressive Dissent, 84 L. Pol. \& Soc'y 109 (2020),

Available at: https://digitalcommons.law.uga.edu/fac_artchop/1369

This Book Chapter is brought to you for free and open access by the Faculty Scholarship at Digital Commons @ University of Georgia School of Law. It has been accepted for inclusion in Scholarly Works by an authorized administrator of Digital Commons @ University of Georgia School of Law. Please share how you have benefited from this access For more information, please contact tstriepe@uga.edu. 


\title{
CHAPTER 5
}

\section{ALL THE BORDER'S A STAGE: HUMANITARIAN AID AS EXPRESSIVE DISSENT}

\author{
Jason A. Cade
}

\begin{abstract}
Immigration enforcement along the Southwest border between United States and Mexico has long channeled migrants into perilous desert corridors, where many thousands have died, out of general public view. In response to this humanitarian crisis, activists from organizations such as No More Deaths (NMD) trek deep into the treacherous desert, hoping to save lives, honor the remains of those who did not survive, and influence public opinion about border enforcement policies. $N M D^{\prime}$ 's activism is not merely utilitarian but also deeply expressive; ultimately, they hope to convey the message that all lives - including those of unauthorized migrants - are worth saving. The Trump Administration has escalated repressive tactics intended to silence these forms of border-policy dissent. Some federal land managers now blacklist NMD, preemptively denying requests for access permits. Meanwhile, the US Attorney's office has aggressively prosecuted members for humanitarian activities. This chapter explains the expressive components of humanitarian activism in this context and of the government's attempt to suppress it, suggesting the need for constitutional scrutiny and legal change.
\end{abstract}

Keywords: immigration; migration; border security; dissent; democracy; civil disobedience; free speech; first amendment

Studies in Law, Politics, and Society

Studies in Law, Politics, and Society, Volume 84, 109-134

Copyright (C) 2020 Jason A. Cade. Published under exclusive license.

All rights of reproduction in any form reserved

ISSN: 1059-4337/doi:10.1108/S1059-433720200000084008 


\section{INTRODUCTION}

On June 25, 2019, Oscar Martinez Ramirez and his 23-month-old daughter Valeria perished in a failed attempt to swim across the Rio Grande to enter the United States (Ahmed \& Semple, 2019). Earlier that day, they were turned away from the international bridge at Matamoros, where they had hoped to seek asylum after traveling 1,000 miles from their home in El Salvador. The widely disseminated photograph of their lifeless bodies lying face down on the muddy riverbank, the toddler's tiny head tucked inside her father's shirt, is forever seared into the memories of many Americans.

Deaths such as these are neither new nor rare-just increasingly visible. Decades of ever more stringent immigration enforcement along the Southwest border between United States and Mexico have pushed migrants into perilous desert corridors. In the remote, deadly stretches beyond Ajo, Arizona, for example, intrepid hikers regularly encounter the bones and belongings of border-crossers who perished on journeys of almost 80 miles. In the last two decades, over 7,000 migrants have died in the border regions, mostly out of public view. With anti-immigrant rhetoric growing louder, and enforcement measures growing harsher, the pressure on migrants to risk their lives in the desert has only increased.

In response to this humanitarian crisis, activists from organizations such as No More Deaths (NMD) trek deep into the treacherous desert, seeking to expand migrant access to water and medical aid, to document and honor the human remains of those who did not survive the journey, and, ultimately, to exert influence on public opinion about border enforcement policies. In this chapter, I examine this activity and argue that the actions engaged in by members of NMD transcend the private, humanitarian efforts of Good Samaritans. Their conduct, and the extensive messaging around it, is in fact deeply expressive. In a pointed and meaningful way, they act as citizen dissenters, engaging in a form of open protest at the precise location where their government is pursuing policies that they condemn and desire to change. In particular, the group seeks to convey the messages that no human should be denied lifesaving aid, that local and global consciousness should be raised about the suffering caused by militarization of the border, and that immigration policies must become more humane. By exposing the otherwise unseen consequences of the nation's immigration policies, these activists challenge widespread outlooks about government rhetoric and enforcement practices.

The threat such messages of dissent pose to the status quo is not lost on the federal government. Indeed, the government has replied often, and at times forcefully. For years, NMD has been locked in battle with the Border Patrol, whose agents sometimes systematically destroy the water jugs left by volunteers along the migration routes. In turn, NMD (n.d.-c) publishes scathing reports and videos documenting government abuses, scrawls messages ("Water is Life!") to agents on the jugs it replaces, and continues its grueling marches into the borderlands for both instrumental and symbolic reasons.

Under the Trump Administration, repressive tactics intended to silence these forms of border-policy protest have rapidly escalated. Some federal land managers now blacklist anyone believed to be a member of NMD, preemptively 
denying their requests for access permits. Meanwhile, the Arizona US Attorney's office has aggressively prosecuted members of the organization for humanitarian activities. Early in 2019, four volunteers were convicted of federal regulations that prohibit operating a motor vehicle in a wilderness area, entering a national wildlife refuge without a permit, and abandoning property (i.e., federal littering) (Phillips, 2019). Four more members faced similar charges that were eventually dropped in exchange for hefty civil fines. Activist Scott Warren faced charges of felony harboring and conspiracy to harbor unauthorized noncitizens, with a possible 20 years in prison if convicted. In June 2019, a deadlocked jury was unable to reach a verdict in his trial. Federal prosecutors retried Warren on two of the charges in November 2019, and this time, the jury fully acquitted him (Ingram, 2019).

This chapter investigates the expressive nature of the humanitarian workers' activities and the government's attempts to suppress it. NMD's speech acts in the desert, directed at the heart of the deadly areas where migration has been pushed, aim not only to save lives but also to express the message that all lives are worth saving. The volunteers with NMD (and similar organizations) use the privilege of their citizenship to speak to multiple audiences, including everyday Americans who might otherwise remain unaware of the deadly consequences of US enforcement policies. In a tangible way, NMD's dissenting conduct propels a counternarrative that furthers critical democratic engagement with immigration policy. The government, in turn, seeks to silence (and condemn) this counternarrative through prior restraint and criminal punishment. What the outcomes of Warren's trials suggest, however, is that the government's approach may be out of step with society's values.

The US Supreme Court has held that when the context surrounding an activity would lead a reasonable person to perceive the conduct as conveying some sort of message, First Amendment Free Speech Clause protections may attach. The complexities of doctrine are legion, and this chapter only begins the project of outlining the relevant considerations. Even so, one clear takeaway of even this preliminary review is that government actors - including federal land managers implementing permit schemes, US Attorneys considering criminal charges, and judges overseeing such prosecutions - should give weight to the free speech concerns raised by citizen dissenters' humanitarian activities in the borderlands. Even if the First Amendment ultimately does not protect all of the activists' conduct, it provides a useful frame to consider the expressivist messaging underlying their humanitarian conduct.

This chapter unfolds as follows: Part I summarizes how government border strategies over the last 25 years have channeled migrants in to treacherous crossing points, elevating the tide of deaths outside of general public view. To fortify these enforcement policies, despite the lethal consequences, government officials trade on a siege narrative. Part II then turns to the citizens who register opposition through expressive humanitarian work in the border areas, focusing in particular on NMD. Their work is both instrumental and symbolic, ultimately serving to construct a powerful counter valence to official policy and thetoric. Part III then suggests that NMD's expressive work may have an important constitutional 
dimension, in that the government's attempts to suppress it at least implicates free speech rights protected by the First Amendment. While full exploration of this theme will await further work, I conclude by suggesting ways that federal officials might better facilitate the expressive rights of citizen dissenters engaging in nonviolent, symbolic humanitarian activity, regardless of whether it is conceptualized as speech or a form of civil disobedience regarding matters of urgent

\section{THE GOVERNMENT'S BORDER STRATEGY AND SIEGE NARRATIVE}

A. Twenty-five Years of Prevention-Through-Deterrence Policy

Donald Trump transformed anxiety over the southern border of the United States into the keystone of his successful campaign for President. Tapping into a rising sense of both nationalism and vulnerability - and, at times, appealing even to bald racism - Trump stoked crowds into frenzied chants to "Build that Wall!" Several years into the Trump Administration, this intense focus on immigration retrenchment has yet to wane. The Trump agenda has included discriminatory travel bans (see, e.g., Cover, 2019; Family, 2019), cruel family separation policies (Jacobs, 2019), indiscriminate deportations (Cade, 2018, pp. 435, 464-467), administrative barriers to legal immigration (Chen \& New, 2019; Van Wagtendonk, 2019), and continued insistence on the need for a southern border wall (Trump, 2019b). Each measure is justified as necessary to "regain control" of
security and national identity.

Although much of the Trump Administration's anti-immigrant agenda is surely to the political right of mainstream America, 'the focus on the border as a site for motivating outrage and generating support for restrictive measures is neither new nor limited to a single political party. The current wave of anti-immigrant backlash started to crest in the early 1990s, with government officials along the political spectrum trading on fears of an out-of-control border long before President Trump took office (Andreas, 2009).

Indeed, "prevention through deterrence," the reigning border enforcement strategy, now dates back 25 years (US Border Patrol, 1994). The federal government strategically pumped massive resources in to manpower, fencing, and surveillance measures at the most prevalent entry points, forcing unauthorized migrants into more treacherous areas, removed from public view (Maril, 2011). The increased difficulty and expense of crossing, however, did not ultimately deter migrants from making the attempt (Andreas, 2009). Apprehensions - long considered a proxy for measuring primary migration flows at the southern border - began to increase in Arizona and New Mexico, even as they dropped in El Paso and San Diego. Although diverted, migrants continued to cross, despite the elevated peril and cost.

By conservative estimates, over 7,000 migrants have lost their lives in these desert stretches since 2000 , by which time the prevention-through-deterrence enforcement strategy had taken firm hold (Devereaux, 2019b). As Mary Fan
$(2008$, pp. 702, 703) soberly observed, 
The raised cost that the strategy levied for unauthorized migration turned out to be denominated in life ... Soaring death rates and unabated migrant traffic showed that people were paying the ultimate price rather than being deterred

Thousands of adults, families, and children, seeking a better future, have instead perished by drowning, dehydration, or exhaustion, as they surrender to the desert's relentless climate.

Rising death rates, however, have failed to precipitate meaningful reform. Instead, officials have doubled down on their efforts to exploit public anxiety about an uncontrolled border in order to justify massive resource allocations, disregarding the ever-growing migrant body count in the desert. The current administration has fashioned anti-immigrant speech and policy into a centerpiece of its political platforms. President Trump has referred to noncitizens arriving at the border as "Mexican rapists," "stone cold criminals," "infestations," carriers of disease, and "animals" (see, e.g., BBC News, 2018; Jansen \& Gomez, 2018; Ross, 2016; Stracqualursi, 2018; Walker, 2015). Over the course of a single year, Trump employed "invasion," or some variant, in this context at least 33 times (Greenberg \& Prignano, 2019). Similar inflammatory rhetoric, suggesting the United States is besieged by large numbers of criminals or subhuman undesirables, has become common fare among other public officials as well (see, e.g., Nielsen, 2018; Sessions, 2018). In reality, border apprehensions are well under the historic highs of two decades ago, and those detained in 2019 mostly consisted of families or unaccompanied children presenting themselves to border officials at the first opportunity in hopes of receiving asylum (Meissner \& Gelatt, 2019).

For the Trump Administration, the actual numbers and demographics of those apprehended are irrelevant. Significant political gains follow from keeping the American public focused on the border as an existential threat. Daniel Morales (2013, p. 69) has observed that

the fact of declining unlawful entries does not enter political or legal consciousness ... The problem is that the apprehensions do not mitigate the threat - they only confirm the rightness of being threatened. In this way, enforcement does little but stoke demand for more border apprehensions.

Government officials engineer, and then exploit, the public's thirst for regained control of the border. As the next section explains, they do this to win elections, justify massive border expenditures, and counteract public outrage over intensely cruel deterrence policies like family separation and extended detention.

\section{B. The Instrumentality of the Siege Narrative}

For years, Customs and Border Patrol (CBP) leadership and other government actors have endeavored to persuade citizens that militarization and fortification are needed measures for addressing unlawful immigration (Gulasekaram, 2012, p. 158). The Trump Administration has amplified these entreaties. President Trump himself has whipped public anxiety - not just about security but also about cultural change - to a fever pitch. The siege narrative serves multiple purposes. 
First, the image of invaders at the border generates public support for massive fiscal appropriations. Immigration enforcement agencies receive vastly more dollars than any federal law enforcement agency (Meissner \& Gelatt, 2019, p. 3). Congress allocated $\$ 24$ billion in fiscal year (FY) 2018 to CBP, Immigration and Customs Enforcement, and the Office of Biometric and Identity Management, an amount that totals $34 \%$ more than appropriations for all other federal criminal law enforcement agencies combined (Meissner \& Gelatt, 2019, p. 3). CBP takes the lion's share of this allocation, to the tune of $\$ 16.3$ billion in FY 2018 for border security efforts (Meissner \& Gelatt, 2019, p. 4).

Second, US citizens are bombarded with rhetoric and imagery that ostensibly justifies (or even demands) the government's harsh defensive measures. Family separation and detention, enhanced militarization, and wall construction are cloaked in the guise of necessity, positioning the government as a savior guarding American citizens against foreign invaders. In the "Latino threat narrative," as described by Leo Chavez (2008, p. 2), noncitizen migrants from Latin America become "part of an invading force from south of the border" that threatens to "destroy[ the American way of life."

Hiding the death and suffering of human beings who, as result of official policy, seek safety or work through perilous border crossings is a key part of this project. As anthropologist Jason De León $(2015$, p. 4) has explained, the "goal is to render invisible the innumerable consequences this sociopolitical phenomenon has for the lives and bodies of undocumented people." It works far better, for the government's purposes, if the deaths of those who perish seeking safety or work are hidden from public view. These entrenched structural forces distort the citizenry's views of migrants at the border and, consequently, their assessment of the appropriate response (Morales, 2013, pp. 65, 66).

Finally, the siege narrative, along with the border policies it has naturalized, communicates messages to noncitizens. On the "political stage" that is the US/Mexico border (Andreas, 2009, p. 9), migrants seeking entry come to recognize that their aspirations, their family integrity, and even their lives are expendable. The desert itself is weaponized, vividly and irrevocably conveying the power exercised by the state over migrant bodies (McGuire \& Van Dyke, 2019, p. 58; Reineke, 2019, p. 148). In Robin Reineke's (2019, p. 148) words,

what the deployment of the desert as a weapon actually accomplishes is not to prevent or deter undocumented border crossings, but rather to make such crossings more terrifying and more
destructive to migrants than ever before.

When thousands of bodies of migrants are left to wither and decay in the desert, it marks them and others of their community as "threatening outsiders who are essentially subhuman" (Reineke, 2019, p. 150).

In sum, the US government has proven remarkably adept at marshaling political and financial support for costly and cruel border measures while skillfully hiding the human costs of those policies. But the government is not the only speaker engaged in expressive activity in the region. The borderlands are a place of contested imagery, where citizen dissenter groups also participate in story-building work to influence public understanding and assessment of the border, communicating a starkly different set of messages to the government, citizens, and migrants. 


\section{CITIZEN DISSENT AND CONSTRUCTION OF COUNTERNARRATIVE AT THE BORDER}

Although the US government's policy of funneling migrants into remote deserts has been tremendously successful in hiding the human costs of migration over the last two decades, local activists and humanitarian workers along the border, and particularly in Arizona, have long been shocked by the rising tide of deaths so close to their communities. Notably, Tuscan was the birthplace of the 1980s Sanctuary Movement, a faith-based network that provided legal screening and basic assistance to Central American refugees whose asylum claims were not receiving fair consideration by government officials (Bezdek, 1995, pp. 928931). Many of the activists from that movement, along with a new generation of concerned community members, were galvanized by a desire both to mitigate and to expose the surge in border deaths. A variety of secular and faith-based humanitarian groups have emerged in the region, diverse in some ways but unified by a shared commitment to providing lifesaving aid to distressed migrants (Campbell, 2012, pp. 107-111).

NMD arose as part of this movement. Founded in March 2004 at the MultiFaith Border Conference, the organization's stated mission is "to end death and suffering in the Mexico-US borderlands through civil initiative: people of conscience working openly and in community to uphold fundamental human rights" (NMD, n.d.-a). Although some of NMD's participants have engaged in humanitarian and political activism for decades, the group also includes many young members, including one of its charismatic leaders, Scott Warren. With members willing and physically able to undertake arduous treks into the Sonoran Desert, the group has built a reputation for both expanding lifesaving access to water and other aid in the most deadly border regions and casting light on the fatal consequences of enforcement policies through body-count mapping, photographs, videos, and other forms of counter-storytelling.

\section{A. The Expressive Value of Citizen Dissent at the Border}

Organizations such as NMD condemn border enforcement measures that result in harsh suffering or death. Building on the long history of American abolitionists and civil rights activists, those who engage in this border-area work believe that to ignore or accommodate these US immigration policies is tantamount to condoning them. In the view of NMD, individual human beings should not forfeit their lives simply because they seek safety or employment through irregular migration.

A key feature that distinguishes NMD from similar humanitarian groups is the political messaging that runs through all of its work. The group believes, and wishes to communicate its belief, that citizens have "the right to provide humanitarian assistance" to migrants in distress (NMD, n.d.-a). Among NMD's tenets and goals, as listed on its website, are the following: "Witnessing and responding," "Consciousness raising," "Global movement building," and "Encouraging humane immigration policy" (NMD, n.d.-a). The organization's Faith-Based Principles for Immigration Reform urge the government to adopt more humane policies. Specifically, NMD (n.d.-b) believes that 
These tragic and unnecessary deaths must stop. The border blockade strategy has militarized the U.S.-Mexico border, which drives migrants into remote desert regions yet has failed to stem the flow of immigrants into the United States.

Thus, in parallel fashion with the government, NMD's activities in the borderlands further both instrumental and expressive goals. Indeed, acts of compassion in this area take on meaning precisely because they stand in such stark contrast with the "powerful and dominant forces of violence and erasure they contest" (Reineke, 2019, p. 151).

NMD's distribution of water, food, and other aid also serves its larger policy agenda. The organization's newsletters, website, and policy statements trumpet the values that lie behind its activities. They also register, in no uncertain terms, the organization's dissenting view of official government policy. The groups' publications emphasize the theme of resistance, through the provision of humanitarian aid, to the border enforcement policies that put migrant lives in danger. ${ }^{2}$

Even the minute details of the humanitarian dissenters' borderland activities are often imbued with deeper meaning. For example, take this account of Scott Warren's conduct when he encounters the remains of deceased migrants, as reported by Ryan Devereaux (2019b):

\footnotetext{
Scott Warren has a checklist he goes through every time he finds a body in the desert. The earthly components are straightforward. Log the GPS coordinates. Take photographs and notes. Scour the brush for more bones .... But for Warren, the process doesn't end there. Warren believes that these moments merit an acknowledgement of humanity. And so, after years of recoveries, the 36-year-old has developed a modest ritual for the grim encounters. He goes quiet, lowers himself to the earth, collects the dirt around him, and then lets the soil pour through his fingers. The point, Warren says, is to take a moment to reflect or, as he puts it, "hold space."
}

Warren's ritual transcends the physical acts of walking in the desert, setting out water jugs, and mapping the locations of the deceased. His solemn conduct, when face to face with the human cost of border policies, communicates. When it is observed by or relayed to others, it is an act that "speaks" - to himself, to perpetrators of those policies, to families of the deceased, and to any observer - more effectively than mere words might. It communicates the deepest of feelings, on par with well-recognized religious ceremonies. It expresses grief and a powerful sense of loss, like the flying of a flag at half-mast.

Importantly, a compassionate treatment of the dead by humanitarian workers in the desert stands in stark contrast to the message conveyed by the state's neglect of those same migrant bodies. Mistreatment of the dead - including failing to properly care for their remains - is a form of violence, especially when it occurs on a collective scale (Reineke, 2019, pp. 150-155). Because this kind of violence is symbolic, it can lead to more violence and social unrest. Moreover, such violence, writes De León (2015, p. 71) is "easily outsourced to animals, nature, or technology." Thus, when civilians engage in discovering, honoring, and recovering the remains of deceased migrants that state policy leaves uncared-for, such actions communicate messages of dissent, working to shift cultural thinking about the value of such lives.

Indeed, in many contexts, the simple act of sharing water itself takes on expressive qualities. Water frequently appears in the Bible as a synonym for salvation, 
while baptism rituals are thought to symbolically bestow new life on the recipient (Cooper, 1978). Indeed, the expressive aspects of water and its distribution date back to the origins of the earliest human life.

NMD's provision of water to migrants in the desert parallels this life-giving imagery. The group views water jugs not just as means of rescue but also as a symbol of the sanctity of life. The sharing of water also signals the right of citizens to provide aid to those in distress. In one video produced by NMD and released on the popular video-sharing site YouTube, which shows CBP destroying water jugs and other supplies left by volunteers in the desert, an activist scrawls "Water is Life" on one of the replacement containers (NMD, 2013). Unmistakably, Border Patrol agents and other government officials are an intended audience for these communications of NMD's beliefs about human dignity and survival, a point driven home by the inscription. Indeed, the author of the message comments in the video that those who intentionally destroy the water are "murderers." By speaking directly, through the water jug inscription, to the perpetrators of policies that the group opposes, and by further sharing that "speech" in a public video with multiple audiences, the expressive content of sharing water is reinforced. ${ }^{3}$

In these contexts, sharing water is symbolic of a distinct American tradition one of generosity, community, opportunity, and shared struggle. Additionally, the particular circumstances in which NMD attempts to share water communicates the group's belief that the right to save lives is important enough to risk physical difficulty and injury, as well as fines and even jail time.

Sharing sustenance, ceremonially documenting the deceased, exposing border violence, and witnessing Border Patrol abuses are all acts that send messages. The expression of concern, community, and conscience that NMD intends to convey through the act of sharing water in the desert challenges other citizens' expectations for militarized border policy and toleration of its consequences. Through their acts of kindness, defiance, and risk, the activists in NMD generate thought and debate among US citizens more broadly.

Indeed, there are many audiences for this kind of messaging, both in the United States and abroad. In particular, the humanitarian work communicates to migrants and their families the idea that not all citizens of the United States see their lives as unworthy of preservation. Meanwhile, US students who partake in NMD's alternative-Spring Break program soon grasp the wider symbolic import of the volunteer's humanitarian efforts. One of the organization's newsletters explains that

students come to understand, especially now as anti-immigrant/migrant sentiment permeates our society, how important it is to participate in justice work and to stand in solidarity with people who are victimized by our oppressive and deadly institutional practices. (NMD, 2016)

NMD's work also pushes back against the stock stories generated by the government in order to justify current enforcement policies and to suppress or normalize the violent consequences of these policies. While these narratives did not originate with the current administration, President Trump has propagated them with renewed vigor. Migrants at the southern border are referred to as "Druggies, 
drug dealers, rapists and killers" (realDonaldTrump, 20I5), terrorists (Trump, 2019), and "Mexico's worst people" (Devereaux, 2019b). Although these tropes may resonate most deeply with nationalists and the President's far-right base (Iftikhar, 2019), the rhetoric encourages all Americans to think about border policy in ways that dehumanize migrants and justify cruel treatment or even death. In this narrative, migrants are either the invading enemy - requiring violent and severe measures to defend against - or they are subhuman hordes (Cade, 2018, p. 480). Either way, they constitute an existential threat to be drastically reduced, if not fully eliminated.

NMD and other humanitarian workers in the desert challenge these narratives, confronting their audiences with new stories. These counter-stories bring the invisible to light. They exchange faceless statistics for individual bodies, bones, and crosses. Observers let other citizens know, for example, that after migrants die in the desert, they first lose their fingers and faces as vultures, coyotes, and insects descend upon them (Devereaux, 2019b). Observers let us know what happens when migrants experiencing hyperthermia "begin to cook from the inside, accelerating decomposition after death," becoming unrecognizable after just a single "summer day in the desert" (Reineke, 2019, p. 152). These kinds of witnessed, visceral descriptions provide far more powerful tools of persuasion than does a generic, detached statement to the effect that border policies push migrants into dangerous terrain.

NMD and similar groups thus disrupt the government's imagery, by humanizing migrants - both living and deceased - and calling attention to the human costs and abuses of border policies through their own expressive counter-activity. In this way, the citizen volunteers in groups like NMD follow through on their felt obligation to push back against the desire for protection and exclusivity that dominates current debate.

Arguably, that counternarrative would be ineffective without expressive action. Indeed, there may be no other means by which the volunteers can persuasively communicate this message but on the same stage in which border officials orchestrate their own dramaturgical roles and goals. "The speech of reason" simply cannot overcome "autocratic exclusion and the stunning amount of force deployed to vindicate it" (Morales, 2017, p. 761). Put differently, citizen dissenters can only hope to rescript the theater of the border that is created by both government actors and migrant crossers through their own dramatic participation.

The efficacy of NMD's expressive activity is also contingent on the location in which it occurs. The borderlands are "content correlated," meaning that the specific attributes of the desert region where unauthorized migration is channeled are critical aspects of the expression that occurs there (Zick, 2006b, pp. 588, 618). As First Amendment scholar Timothy Zick (2006b, p. 621) has argued, "places are not given but made." Rules, norms, and social processes, Zick (2006b, pp. 621, 622) continues, transform "raw material of undifferentiated space" into expressive place. Those in society with the most power, such as government managers, exercise control over the appropriate uses of a space and thereby have an outsized role in establishing its expressive content. Government officials construct places to reify their power and justify their preferences. In this way, "place manifests power," which can then be used to suppress agitators or particular 
viewpoints that threaten the status quo (Zick, 2006b, p. 623). Seen in this light, there may be no other means by which organizations like NMD might effectively challenge the government's messaging about unauthorized migration in the desert regions except through the creation of new experiences and practices in that same setting.

As Richard Delgado (1989) explained, stories can produce lasting change because they are capable of inflicting permanent damage to a stock story or dominant narrative (p. 2429). Counter-stories that are forged through actual experience force the audience to confront the dominant narrative and reevaluate it in light of the new world view presented. Accordingly, counter-stories, when effective, are deeply registered and constructive.

It is through this process that we can overcome ethnocentrism and the unthinking conviction that our way of seeing the world is the only one - that the way things are is inevitable, natural, just, and best - when it is, for some, full of pain, exclusion, and both petty and major tyranny.

(Delgado, 1989, p. 2439)

In undertaking their arduous border-region treks, leaving out water jugs, and mapping the remains of the deceased, NMD volunteers allow us to begin to understand the meaning of a place we have never been. These kinds of personal, eye-witness accounts are critical modes of resistance and dissent (Lindo, Williams, \& González, 2018, pp. 797, 798). The stories told by NMD help one grasp the actual reality of the border crossing experience - and the consequences of severe deterrence policies - rather than the imagined distant abstraction that would otherwise prevail. Other citizens learn from their experiences and expression of those experiences (Lindo et al., 2018, pp. 798-800). Through defiance of land managers, Border Patrol, and federal prosecutors, undertaken with the goal of saving lives and promoting the right to save lives, NMD contests the status quo, disrupting other citizens' complacency with current border policies. Their stories challenge dominant stories and ideologies. Mere awareness of the organization's work in the border regions begins to transform the social construction of that place. By galvanizing awareness of, and support for, their project, the humanitarian activists materialize alternative accounts of how humans can or should treat each other. In these ways, they "build consensus ... and deeper, more vital ethics" (Delgado, 1989, p. 2414).

To be sure, citizen activists in groups like NMD do not hold a monopoly on the construction of counter-stories in the borderlands. Militiamen and other antiimmigrant restrictionists also engage in a project of storytelling in the region, a point to which I will return later. Noncitizens - especially the migrants themselves - also have something to say about the merits of current border enforcement policy. Their stories differ significantly from the stock narrative told within the United States, in viewpoint, content, and tone, and would therefore offer an important contribution to public discussion. But at the same time, it is indisputable that their views are given little weight, on account of their outsider status (Morales, 2013, p. 49; Song, 2019, pp. 53-73). NMD, as a collection of citizen dissenters, thus helps give voice to the silenced - or, at least discounted - voices of migrant outsiders. 
Importantly, the group's activists are making and telling stories not only on behalf of the migrants they seek to keep alive but also on behalf of themselves. This matters, because the volunteers working at the border are also a kind of outsider group, despite their privileged citizenship status. Their values and perspectives differ from the government, and likely from many citizens within the United States. Indeed, this nonmainstream viewpoint is part of the reason their activities have led to substantial government suppression and prosecution. At the same time, the stories they tell through their activities, reports, and videos help distribute and ultimately normalize their outsider perspective (Lindo et al., 2018, pp. 797, 798). The fact that NMD's activities in this context have multiple messages and multiple audiences only serves to emphasize their significance. Indeed, expressive conduct, like any other form of communication, will often mean different things for the speaker and the audience, but that does not cheapen its value.

NMD recognizes that its mission faces overwhelming opposition from the government, and especially so since the Arizona US Attorney's office began the recent spate of aggressive prosecutions, as I discuss further below. But, for present purposes, the fact that the activists face real risk and opposition as they attempt to provide lifesaving aid also reinforces the expressive quality of their conduct, demonstrating in tangible ways the firmness of their conviction that current actions by Border Patrol and other officials are wrong.

Although knowing their actions to be partly symbolic, activists forge ahead because they believe it to be their right and duty as concerned citizens to protest abusive government policies. If the government is unable or unwilling to live up to the United States' humanitarian values, as NMD believes, conscientious citizens must help implement those ideals, even at the risk of criminal prosecution and other costs. Their work therefore can push society toward a more humane conception of immigration enforcement and, ideally, reshape prevailing norms (Cade, 2018, p. 496).

\section{GOVERNMENT SUPPRESSION OF NMD'S EXPRESSIVE CONDUCT RAISES CONSTITUTIONAL CONCERNS}

\section{A. Government Suppression of Citizen Dissenters}

NMD's activities have long positioned it in an antagonistic relationship with Border Patrol and other federal officials. In recent years, these conflicts have reached a boiling point. As the organization characterizes it, federal policy has led land managers "away from productive collaboration with humanitarian aid groups and toward a racist national administration that puts pressure on all government agencies to uphold a white supremacist agenda" (NMD, n.d.-d). While this language is inflammatory, support can be found for the contention that federal officials desire to suppress NMD's dissenting activities.

In 2017, for example, land managers forged a plan with other federal agencies to directly target humanitarian activities undertaken by NMD (Devereaux, 2019a, p. 6). The core of the scheme was to change the permitting rules such that 
any visitors onto Cabeza Prieta (which contains the Ajo corridor now regularly used for unauthorized migration) would first be required to acknowledge that it was unlawful to "abandon" personal property in that area, and that such personal items included water containers, food, and similar aid (Devereaux, 2019b).

Federal land managers' private communications (obtained through discovery in court proceedings) suggest that a primary motivation behind this abrupt policy change was not to combat littering in a fragile ecosystem, but rather to address internal frustration that humanitarian activists' aid efforts "can help energize folks to hike another day or two," and "thus continue their journey." (Devereaux, 2019a, p. 8). Outrage over the fact that NMD's attempts to preserve human life might help facilitate irregular migration led at least one federal official to preemptively deny permits to anyone suspected of being affiliated with the organization. Sidney Sloane, a manager of the Cabeza Prieta Wildlife Refuge, testified in criminal prosecutions of the targeted activists that he had "a number of ways" to detect whether a permit-seeker was working with NMD. In essence, any person. triggering his suspicions was placed on a no-permit blacklist, which was routinely shared with other federal managers (Devereaux, 2019a, pp. 8-10, 12). ${ }^{4}$ Notably, no individuals other than suspected NMD volunteers appear to have ever been preemptively banned from the refuge (Devereaux, 2019b).

Tensions between humanitarian activists and CBP have become particularly fraught. On January 17, 2018, NMD published footage exposing the CBP's destruction of thousands of gallons of water that activists had left for migrants in the scorching desert (NMD, 2018). The government promptly retaliated (Devereaux, 2019b). That morning, Scott Warren had traveled to "The Barn" - a humble structure outside of Ajo and just 40 miles from the border - to wait for a student group. The Barn serves as a focal point for the organization's humanitarian efforts and is a gathering place for students and volunteers who come to learn about the harsh reality of the borderlands for migrants. Migrants who trek through the desert sometimes find temporary aid there. As it turned out, two Central American migrants recently had taken brief refuge. Having learned of their presence, a caravan of Border Patrol agents stormed the structure with firearms drawn and arrested Warren and the two migrants. A grand jury subsequently indicted the activist on two counts of harboring and one count of conspiracy to harbor unauthorized noncitizens (Devereaux, 2019b). Warren and eight other NMD volunteers were also charged with additional minor offenses for violating access rules and leaving water jugs out for migrants in a National Wildlife Range.

Scott Warren's first case went to trial in May 2019. Ultimately, the jury was unable to reach a verdict on any of the felony counts, resulting in a mistrial (Shuham, 2019). Federal prosecutors retried Warren on two of the counts in November 2019. This time, Warren was fully acquitted (Brean, 2019). In a separate bench trial, US District Court Judge Raner C. Collins found him guilty of unauthorized operation of a motor vehicle in federal lands but acquitted him of the federal littering charges on religious liberty grounds.

Unmistakably, the prosecutions, and related attempts to suppress the volunteers symbolically express official rejection of the citizenry's humanitarian 
impulses, or at least those impulses that challenge accepted narratives around border policy. Indeed, the US Attorney for Arizona who prosecuted Warren warned after the loss that his office would continue to aggressively prosecute those who provide aid to migrants even if "they're doing it out of what I would say (is a) misguided sense of social justice" (Brean, 2019). Legal prohibitions and punishments always express the state's perception of threat, as well as its desire for obedience (Garland, 1990). In Joseph Gusfield's (1981, pp. 159, 181) formulation, the "public drama of law provides the expectations and perceptions of what is normal and acclaimed and what is deviant and condemned." At the border, the government's strength as expressed through an aggressive security program has tended to be politically popular. The fact that this seems to be less true recently with respect to some of the Trump Administration's more extreme measures only serves to make any dissenting activity that gains traction all the more threatening.

The humanitarian work undertaken by Warren and other dissenters challenges the dominant social order and the legitimacy of government force employed to sustain it. The federal prosecutions thus are designed to destroy or mitigate that threat. More specifically, when the government prosecutes citizen dissenters who attempt to provide aid to migrants or to make visible those who perish in the desert, it seeks to suppress the counternarrative that migrants are fully human and worthy of our care and compassion (Reineke, 2019, p. 154).

These dissent-quashing prosecutions are no isolated occurrence. Distaste for dissent, as a broader milieu in America at this moment, is reflected in and to some extent seeded by President Trump's rhetoric and policies. From the top of the administration on down, the "unmistakable message," as Timothy Zick (2018a, p. 1444) has written, "is that even minor acts of civil disobedience will be met with severe punishment." Of particular relevance, federal prosecutions of persons suspected of helping noncitizens, including through provision of water or other humanitarian aid, have increased by 30\% since 2015 (Matalon, 2019). In FY 2018, there were 4,532 such prosecutions (Matalon, 2019). The US Attorney for Arizona has made clear that his agency's failure to achieve a conviction of Warren (twice) will not deter continued aggressive prosecutions of humanitarian workers (Brean, 2019). Unambiguously, the federal government hopes to suppress and intimidate further humanitarian dissent with the full weight of the law.

Meanwhile, the government affords wide latitude to both privateers traveling to the region to construct unofficial border walls and vigilante nationalists rounding up migrants at gunpoint (see, e.g., Nathan \& Rozensky, 2019; Romero, 2019). Indeed, the efforts of such groups are often welcomed and celebrated by the Trump Administration and its close allies, and their leaders enjoy a loud platform from which to defend and promote their restrictionist activities (see, e.g., Hancock, 2019; Schreckinger, 2019). NMD's viewpoint, as expressed through its own border-region activities, thus provides a valuable counternarrative, despite and because of - the government's attempts to suppress it through intimidation, restriction, and prosecution.

Warren's acquittal on the harboring charges has expressive significance too, of course. In light of the fact that Warren took the stand and admitted to the 
conduct charged by the government, the acquittal signifies that 12 jurors directly rejected the claim that his humanitarian work should be punished as a crime. In this sense, the outcome represented a nullification of the US Attorney's decision to bring the full hammer of the law down upon the activist (McAdams, 2009, p. 552). While it is unlikely that prosecutors will soon change their stance regarding humanitarian activity, the jury's message about overreach in this context was clear.

\section{B. Humanitarian Aid as Protected Speech}

The previous sections of this chapter offered a thick description of the expressive significance of NMD's humanitarian work on the border and of the government's suppression of that conduct. As suggested earlier, because key parts of the activists' work are symbolic, and would be reasonably understood to convey broader meaning, suppression of those activities through permitting schemes and criminal prosecution might require constitutional scrutiny. In subsequent projects, I will take up a full exploration of the issues raised by the possible application of the First Amendment in this context. Here, my aim is to outline the threshold consideration; namely, why at least some of NMD's humanitarian activities could be classified as "speech."

The free speech frame is useful because it helps bring into sharper relief the problematic aspects of the government's attempts to suppress NMD's humanitarian activity with prior restraints and the full weight of the criminal law. Even if courts ultimately would not hold that the constitution prevents the government from regulating humanitarian work in the border regions, recognizing its approach as designed to suppress nonviolent dissenting conduct may pave the way for important executive or legislative legal reforms in the future.

The Supreme Court has long held that "the Constitution looks beyond written or spoken words as mediums of expression" (Hurley v. Irish-Am. Gay, Lesbian \& Bisexual Grp. of Boston, 1995). The autonomy and self-determination values protected by the First Amendment, Robert Post (2011, p. 479) has written, "extend] not merely to the speech of persons but also to the actions of persons." Over the years, the Court has found a variety of expressive conduct to warrant constitutional protection, including cross burning (Virginia v. Black, 2003), flag burning (Texas v. Johnson, 1989), parading (Nat'l Socialist Party v. Vill. of Skokie, 1977), and much more (see, e.g., Am. Booksellers Ass'n, Inc. v. Hudnut, 1986; Schacht v. United States, 1970).

To be sure, not all conduct is sufficiently expressive to warrant First Amendment coverage. As an initial matter, the actor must have some "intent to convey a particularized message" through the action (Spence v. Washington, 1974). Additionally, a reasonable observer must necessarily interpret the activity as conveying "some sort of message" (Holloman ex rel. Holloman v. Harland, 2004). For conduct to be sufficiently expressive, however, the observer need not "infer a specific message" (Holloman ex rel. Holloman v. Harland, 2004). As the Supreme Court (Hurley v. Irish-Am. Gay, Lesbian \& Bisexual Grp. of Boston, 1995) has opined, 


\begin{abstract}
a narrow, succinctly articulable message is not a condition of constitutional protection, which if confined to expressions conveying a "particularized message," would never reach the unquestionably shielded painting of Jackson Pollock, music of Arnold Schöenberg, or Jabberwocky verse of Lewis Carroll.
\end{abstract}

Although the message test as set out in Spence and its progeny has been much criticized, it remains the doctrinal starting point for assessing whether symbolic conduct warrants First Amendment coverage (McGoldrick, 2008).

Close engagement with the relevant context suggests that sharing water with distressed migrants in the desert and honoring the remains of those who have perished in its harsh climate may well qualify as forms of expressive messaging within the meaning of the First Amendment. In Fort Lauderdale Food Not Bombs v. City of Fort Lauderdale, a 2018 case from the Eleventh Circuit Court of Appeals, the court relied on the First Amendment to find unconstitutional a government ordinance prohibiting a nonprofit from sharing food at no cost with homeless persons in a public park. The court concluded that the organization Fort Lauderdale Food Not Bombs (FLFNB) engaged in "peaceful direct action" warranting constitutional protection when distributing food to the homeless in a public park in downtown Fort Lauderdale. Much of the Court's analysis in Fort Lauderdale Food Not Bombs is relevant to the free speech analysis of NMD's somewhat similar humanitarian expression.

As the Eleventh Circuit emphasized, the context around an activity is key to the determination of its expressive content.

History may have been quite different had the Boston Tea Party been viewed as mere dislike for a certain brew and not a political protest against the taxation of the American colonies without representation. (Fort Lauderdale Food Not Bombs v. City of Fort Lauderdale, 2018, p. 1241)

Indeed, the simple act of presence in a particular place can be expressive (Emerson, 1970, p. 293; Smolla, 1992, p. 26). "Context separates the physical act of walking from the expressive conduct associated with a picket line or a parade" (Fort Lauderdale Food Not Bombs v. City of Fort Lauderdale, 2018, p. 1241). In a parade, those who march are "making some sort of collective point, not just to each other but to bystanders along the way" (Hurley, 1995, p. 568). Similarly, a "sit-in" to protest a segregated library conveys meaning even though the act of sitting typically lacks expression (Fort Lauderdale Food Not Bombs v. City of Fort Lauderdale, 2018, p. 1241). Context explains why nude dancing may receive constitutional scrutiny although nudity itself is not inherently expressive (City of Erie v. Pap's A.M., 2000).

In the case before it, the Eleventh Circuit found particularly relevant: (1) the public interest in the issue of homelessness, (2) the historical symbolism of sharing food, (3) the location FLFNB chose for its expressive conduct, and (4) the audiences who might observe and react to the organization's intended message. Regarding the public interest in the particular issue, the court found that the food-sharing activities were related to "an issue of concern in the community," namely, "the treatment of the City's homeless population" (Fort Lauderdale Food Not Bombs v. City of Fort Lauderdale, 2018, p. 1242). Elected officials previously had held a public workshop to address concerns about homelessness and local media had covered the City's homeless population. This local discussion, the 
court opined, "provides background for FLFNB's events," and thereby "adds to the likelihood that the reasonable observer would understand that FLFNB's food sharing sought to convey some message" (Fort Lauderdale Food Not Bombs v. City of Fort Lauderdale, 2018, p. 1242).

Similarly, the consequences of border policies are issues of particular concern for local communities in southern Arizona and elsewhere along the US/Mexico border. Increasingly, residents throughout the United States are also concerned about border policy and migrants. Borderland activities of various sorts, undertaken by both the government and private actors, have long been points of contention and debate. As discussed previously the prevention through deterrence strategy has been costly, in terms of resources expended, the loss of human life, and the rising consternation felt by local residents in border communities.

A second contextual factor from the Eleventh Circuit case concerns the historical symbolism of the expressive conduct. As the court observed,

it matters that FLFNB uses the sharing of food as the means for conveying its message, for the history of a particular symbol or type of conduct is instructive in determining whether the reasonable observer may infer some message when viewing it. (Fort Lauderdale Food Not Bombs v. City of Fort Lauderdale, 2018, p. 1243)

The court continued:

the significance of sharing meals with others dates back millennia. The Bible recounts that Jesus shared meals with tax collectors and sinners to demonstrate that they were not outcasts in his eyes. In 1621, Pilgrims and Native Americans celebrated the harvest by sharing the First Thanksgiving in Plymouth. (Fort Lauderdale Food Not Bombs v. City of Fort Lauderdale, 2018, p. 1243)

The historical importance of sharing sustenance, including with those that many in society would deem to be outsiders, also helps contextualize NMD's conduct as expressive activity. The activists provide water and other aid to those in distress, not solely to save individual lives but also to make the collective points that all lives are worth saving and that, as fellow humans, our society has both an obligation and a right to help those less fortunate, regardless of immigration status.

The location of FLFNB's conduct was also relevant to the constitutional analysis in that case. In general, government-owned parks tend to be considered public forums for First Amendment purposes (see, e.g., Berger v. City of Seattle, 2009). Importantly, though, the Eleventh Circuit did not rest its analysis on that fact alone. Rather, what the court found especially significant was the fact that the site chosen by FLFNB for its expressive activity was "known in the community as a location where the homeless tend to congregate" and was a long-standing place of "battleground over the City's attempts to reduce the visibility of homelessness" (Fort Lauderdale Food Not Bombs v. City of Fort Lauderdale, 2018, p. 1238). As the Court of Appeals noted, "[a]lthough the choice of location alone is not dispositive, it is nevertheless an important factor in the "factual context and environment" to be considered (Fort Lauderdale Food Not Bombs v. City of Fort Lauderdale, 2018, p. 1243).

Although federally owned, with an opportunity for public access through a permitting scheme, desert preserves would not likely be deemed traditional public forums. Nevertheless, it is indisputable that the particularity of a place can be 
critical to the content and impact of speakers' expression. The place in which speech or speech acts occur "profoundly impacts expressive message, persuasive efficacy, participation, and symbolic meaning" (Zick, 2006a, p. 439). By engaging in humanizing acts of compassion in the same terrain that federal officials have weaponized against migrants, NMD's activities engage in a contest over the place's expressive meaning itself. The complex messaging of their actions would lose their force if engaged in far from the borderland desert. Thus, the choice of location helps imbue the activists' work with expressive meaning.

The fourth and final contextual factor to highlight here concerns the audiences of the expressive activities. As the Eleventh Circuit noted, FLFNB's events are not closed, such that anyone present can partake in sharing meals together. The organization also sets up tables and banners. The visibility of FLFNB's activities, such that others might witness and reflect on their import in the context of government policies that affect the homeless, contributed to the Court's conclusion that "FLFNB's food sharing events are more than a picnic in the park" (Fort Lauderdale Food Not Bombs v. City of Fort Lauderdale, 2018, p. 1242).

While NMD's parallel humanitarian work occurs in far more isolated locations, much of it takes place in the open, on government lands. Though remote, the dissenters' gestures are visible to each other, CBP, migrants, students, and any others present in the area. More importantly, however, through publication of their videos, reports, and newsletters, as well as through media attention on their conduct and the government's responses to it, the activists' expression disseminates to a wider public, including other citizens throughout the United States. Finally, to a lesser but still relevant extent, the activists sometimes scrawl literal messages on the containers they sets out, directly underscoring the implied expressive message to their audiences that "water is life." These various means of transmission have increased public awareness of the consequences of border policy for migrants and the work of activists who express opposition to those policies in the desert regions where migrants are channeled. Like FLFNB, NMD has made efforts to galvanize public attention on the issues.

Considering all the contextual factors present in Fort Lauderdale Food Not Bombs, the Eleventh Circuit determined that FLFNB's food sharing conveyed a political message, rather than solely constituting an act of charity. The organization's work promotes alternative ideas about poverty and the need for humanitarian distribution of resources. Consequently, the court held that the City's application of an ordinance to restrict their food-sharing activities violated the constitution.

In light of this closely related precedent, and the guideposts set forth by the US Supreme Court, the key parts of NMD's humanitarian work arguably constitute expressive activity covered by the First Amendment. A reasonable observer would likely understand the group's activity as expressing concern for migrants, a belief in the right to provide humanitarian aid, and opposition to the federal immigration policies that have created a humanitarian crisis in the border regions, although that level of message specificity is unnecessary for purposes of recognizing the activity as constitutionally covered speech. 
Recognizing much of NMD's humanitarian work as constitutionally-covered expressive activity would promote core values that the First Amendment is intended to safeguard. A primary purpose of the First Amendment is the protection of speech that is unpopular, controversial, or disruptive of the status quo (Shiffrin, 2000, p. 10). The U.S. Supreme Court has opined that speech "may indeed serve its high purpose when it induces a condition of unrest, creates dissatisfaction with conditions as they are, or even stirs people to anger" (Terminiello v. City of Chicago, 1949). Dominant groups employ stock stories in order to construct a reality that justifies their privileged (and typically oppressive) position (Delgado, 1989, p. 2437). In the context of border enforcement, the official rationalizing narrative is that Americans are simply doing what is necessary to protect against invaders and criminals. It is an innocence-preserving narrative in the face of significant suffering. The humanitarian volunteers' aid efforts establish a critique of this position (Fan, 2008, p. 720). They challenge dominant beliefs by unearthing and constructing knowledge that would otherwise be ignored or remain unknown. In this sense, recognizing at least some of the dissenters' humanitarian work as protected speech would further the classic First Amendment value of "promoting diversity of ideas" in public debate (Magarian, 2017 , p. xvii). For its continued survival, democracy needs sufficient protection for those who dare to peacefully criticize government policies.

The First Amendment's protections for speech are also intended to promote individual autonomy and self-definition. Our diverse society cannot always reach a public consensus about controversial issues; as a result, people with clashing ideas must find ways to coexist. "The constitutional right of free expression is powerful medicine in a society as diverse and populous as ours" (Cohen v. California, 1971, p. 24). Thus, free speech is important not just for the pursuit of truth, or as a check on problematic government policy, but because self-expression is a means to more personal objectives such as self-development and moral independence (see, e.g., Richards, 1999, pp. 21-28; Sunstein, 1993, pp. 129, 130). Professor Magarian (2017, p. xvii) refers to this as the "participation value" of the First Amendment. In Edwin Baker's (1989, p. 5) formulation of this concept, the First Amendment protects "an arena of individual liberty." Others have described it as a constitutional guarantee of freedom of conscience.

Regardless of how this value is characterized, the point is that allowing individuals to engage in self-expressive conduct without unconstitutional government restriction protects our freedom to define ourselves in a diverse society, which in turn promotes social stability (Emerson, 1963, pp. 4, 5). From this perspective, citizens may undertake humanitarian activities in the desert in order to define themselves in the public sphere as opposed to various government policies, as much as to hope to change policy or sway public opinion (Baker, 1989, p. 53).

This last point provides an opportunity to address potential concerns that the foregoing analysis would support First Amendment protection for any actions taken pursuant to a set of values, including expressive activities that are repressive or violent, such as the roving militia who round up migrants at gunpoint or citizens who help construct private border walls. As an initial matter, one must concede that even violent acts in certain contexts undoubtedly can be expressive. 
Nevertheless, terrorist attacks, political assassinations, racially motivated violence, sexual assault, and other violent acts or unduly coercive speech acts fail to receive constitutional protection because of the impact on others, who have their own individual rights to autonomy and participation in a free society (Baker, 1989, pp. 51-73). Indeed, most courts treat such conduct as outside of the First Amendment altogether, implicitly recognizing consensus expectations about social order. For similar reasons, not all forms of communication are protected by law, even those that are pure speech. Pursuant to long-established doctrine, for example, mere words that would reasonably incite imminent violence constitute unprotected speech. It follows, then, that violence itself must be unprotected, even if expressive. Thus, to the extent that anti-immigrant expressive activity in the border becomes violent, threatens to impede the bodily autonomy of others, or unduly restrains their capacity to engage in self-development or social participation, that activity would remain unprotected by the Constitution. There will always be hard cases, of course, but the point is that recognizing humanitarian activity in this very particular context as expressive speech covered by the First Amendment does not mean that all expressive conduct, humanitarian or otherwise, must receive constitutional protection or even constitutional analysis.

If NMD's humanitarian activity is expressive conduct within the ambit of the First Amendment, the government's attempts to restrain or punish it require scrutiny. In the space that remains, I briefly outline some of the concerns. First, the permitting restrictions that managers use to prevent or punish activists from undertaking their humanitarian work, along with the requirement that park visitors not "abandon" personal property such as water jugs, directly collide with NMD activists' desire to express their right to provide humanitarian aid. Generally speaking, permitting requirements that prevent speech (or speech acts) must overcome a presumption against constitutionality (Berger v. City of Seattle, 2009, p. 1037; Kellum, 2008, p. 392). Prior restraint in the First Amendment context is an expansive term, "encompassing any attempt by a public official (including both administrative and judicial orders) to prevent speech in advance of its actual expression" (Tusk, 2003, p. 1226).

Furthermore, the permitting scheme has been implemented in a way that least suggests viewpoint or speaker discrimination. Suspected NMD volunteers apparently have been blacklisted and targeted for arrest on the basis of political disagreement with their activities. If no other permit seekers were preemptively denied access or targeted for retaliation, then the government's conduct suggests hostility against particular viewpoints or speakers. This way of administering the permit regulations had a chilling effect on expression - in particular, on a humanitarian critique of border policy - which in turn negatively constrains various audiences' ability to observe, process, and react to that expression. While the legal analysis is complex and the evidence is still emerging, this apparently discriminatory means of administering the rules warrants attention.

If challenged in court, the legitimacy of the state's rationale for the restrictions as well as evidence of its actual motivations - would be weighed against the strength of the free speech interests at stake (see, e.g., United States v. O'Brien, 1968; Zick, 2018a, pp. 1441, 1442). To be sure, the general permitting system that 
impacts NMD's activities might well be deemed facially reasonable by a Court, since many entrants would not be engaging in expressive activity, and there are legitimate safety concerns in the desert. Nevertheless, the expressive concerns on NMD's side of the ledger are substantial. Indeed, there may be no other way that NMD can effectively communicate its messages except through the sharing of water in the precise locations where the policies that it opposes result in human suffering and death. The powerful message of dissent embodied in the activists' work might well lose all of its expressive content if it could not occur in the border regions (Crocker, 2007, p. 2588).

Framing key humanitarian activity (i.e., sharing water and honoring the dead) in this context as expressive speech - even if ultimately not protected by the First Amendment due to deferential balancing tests - helps put the problematic aspects of the government's repressive approach into sharper relief. Managers have a responsibility to maintain safety in the border regions, but they should take care not to impose severe penalties or prior restraints that go beyond maintenance of the ecosystem or safety and instead suppress expressive humanitarian conduct, or that discriminate on the basis of viewpoint. Indeed, some scholars argue that proper government adherence to the First Amendment requires not only the avoidance of improper restriction but active facilitation of diverse voices (see, e.g., Magarian, 2017, p. 1452; Zick, 2018b, p. 241). There are certainly means by which a less restrictive approach could be taken. The permitting scheme could be revised, for example, such that it allows volunteers to continue with lifesaving aid without prior restraint or civil punishment. Alternatively, the government could maintain restrictions on littering but work out alternative ways for NMD to effectively protest. For example, if activists agree to timely collection of used water jugs, they have not actually "abandoned" personal property. Indeed, NMD already has a practice of collecting trash in the desert, raising further doubt about the government's heavy-handed arrests for violation of the littering regulation in particular.

Lawmakers, too, should take note of the expressive content of humanitarian activists' work in the border. The government's failure to convict Warren (twice), despite his admission to the underlying conduct, suggests a mismatch between the legal prohibitions at issue and societal understandings of right and wrong. Paul Robinson $(2000$, pp. 1868,1869$)$ has written that "to become a moral authority, the criminal law cannot deviate too far from what the community thinks is just, that is, too far from lay intuitions of justice." Jury nullification - which is what these verdicts add up to - sends an especially strong message that legal reform is needed. Perhaps border policies that funnel migrants into dangerous crossings will remain, but that does not preclude other legal changes that might allow for the saving of lives without fear of criminal prosecution.

\section{CONCLUSION}

As this chapter has shown, NMD disrupts the government's control of the border narrative by humanizing migrants, both living and deceased, and calling attention to the costs and abuses of border policies through their own expressive activity. 
The activists hope to improve migration discourse and achieve desired legal reforms. But even if that does not occur, they seek to define themselves by publicly performing their opposition to unjust government policies. From the government's perspective, these citizen dissenters are disruptive hecklers at a play, changing the nature of the drama as it unfolds. The humanitarian narrative therefore must be silenced and erased; if the story of the dead disappears, so do the dead and those sympathetic to their plight.

In the end, whether NMD's symbolic conduct is "speech" or is instead some other form of collective, public civil disobedience may not matter tremendously. Regardless of how it is characterized, the expressive nature of their work and the government's attempt to silence it reveals the need to protect nonviolent, dissenting conduct regarding matters of significant public concern from excessive silencing. Consensus about border policies may not be possible, but coexistence in a diverse society depends in part on allowing disparate viewpoints to emerge, including those that peacefully challenge the status quo and thereby contribute to democratic knowledge. Land managers should take the humanitarian activists' expressive claims seriously in revising or implementing permit schemes, endeavoring to avoid viewpoint restriction or prior restraint of protected activity. Federal prosecutors likewise should take these considerations more seriously when considering criminal charges, as should judges overseeing prosecutions that go forward. And, ultimately, lawmakers should recognize the gap between the government's use of the law to silence humanitarian activists and the apparent lack of societal reproach, necessitating legal reform.

\section{NOTES}

1. The Pew Research Center (2019), for example, reported in August 2019 that $72 \%$ of Americans believe undocumented immigrants should be allowed to stay in the United States legally if certain conditions are met.

2. The group's many public statements evincing desire to shift cultural understandings of migrants' plight and the role of the government in perpetuating death in the desert include the following: "Until the deaths in the desert end, No More Deaths/No Mas Muertes volunteers will walk the migrant trails and give aid to those we meet and those we never see" (Gaffney, 2015). "The light that must continue to shine is active nonviolent resistance to an increasingly oppressive border policy that imperils and terrorizes millions of migrants and immigrants" (No More Deaths, 2017). "It is the duty of humanitarian aid groups to publicly ... expose the Border Patrol policies that cause the deaths and disappearances of migrants crossing the U.S.-Mexico border" (Dinsmore, 2016).

3. The symbolism of water at the border is also reflected in the physical memorial created by the family of two migrants who died of thirst in 2019 while attempting to cross the desert. A relative of the deceased explained that "The water is for my sister and my nephew. That they never lack for a drink again" (McDonnell, 2019).

4. Although one federal official reminded Sloane that it was unlawful to preemptively ban individuals from the permitting process, Sloane was apparently undeterred (Devereaux, 2019a, p. 12). 


\section{ACKNOWLEDGMENTS}

The author is grateful to Muneer Ahmed, Diane Amann, Dan Coenen, Angela Cornell, G. S. Hans, Laila Hlass, Nina Rabin, Sarah Sherman-Stokes, Elizabeth Weeks, and the anonymous reviewer for comments. Thanks to Dan Vo (UGA Law 2020) for research assistance and to T. J. Striepe, George Thomas, and Lauren Lisauskas for reference assistance.

\section{REFERENCES}

Ahmed, A., \& Semple, K. (2019, June 25). Photo of drowned migrants captures pathos of those who risk it all. New York Times. Retrieved from https:/www.nytimes.com/2019/06/25/us/fatherdaughter-border-drowning-picture-mexico.html

Am. Booksellers Ass'n, Inc. v. Hudnut, 475 U.S. 1001 (1986).

Andreas, P. (2009). Border games policing the US-Mexico divide. Ithaca, NY: Cornell University Press. Baker, C. E. (1989). Human liberty and freedom of speech. New York, NY: Oxford University Press.

BBC News. (2018, May 17). Trump: Immigrant gangs "animals, not people," BBC News. Retrieved from https://www.bbc.com/news/av/world-us-canada-44148697/trump-immigrant-gangs-animalsnot-people

Berger v. City of Seattle, 569 F.3d 1029 (9th Cir. 2009).

Bezdek, B. (1995). Religious outlaws: Narratives of legality and the politics of citizen interpretation. Tennessee Law Review, 62, 899-996.

Brean, H. (2019, November 22). Not guilty: Jurors acquit border aid volunteer Scott Warren on harboring charges, Tucson. com. Retrieved from https://ucson.com/news/local/not-guilty-jurors-acquitborder-aid-volunteer-scott-warren-on/article_f5100171-clee-58d2-84b8-9ab85e98ecea.html

Cade, J. A. (2018). Sanctuaries as equitable delegation in an era of mass immigration enforcement. Northwestern University Law Review, 87, 433-504.

Campbell, K. M. (2012). Humanitarian aid is never a crime? The politics of immigration enforcement and the provision of sanctuary. Syracuse Law Review, 63, 71-118.

Chavez, L. (2008). The Latino threat: Constructing immigrants, citizens, and the nation. Stanford, CA: Stanford University Press.

Chen, M. H., \& New, Z. (2019). Silence and the second wall. Southern California Interdisciplinary Law Journal, 549, 558-574.

City of Erie v. Pap's A.M., 529 U.S. 277 (2000).

Cohen v. California, 403 U.S. 15, 26 (1971).

Cooper, C. J. (1978). An illustrated encyclopedia of traditional symbols. London: Thames \& Hudson.

Cover, A. (2019). Quieting the court: Lessons from the Muslim-ban case. Journal of Gender, Race \& Justice, 23, 1-9.

Crocker, T. P. (2007). Displacing dissent: The role of "place" in First Amendment jurisprudence. Fordham Law Review, 75, 2587-2639.

De León, J. (2015) The land of open graves: Living and dying on the migrant trail. Berkeley, CA: University of California Press.

Delgado, R. (1989). Storytelling for oppositionists and others: A plea for narrative, Michigan Law Review, 87, 2411-2441.

Devereaux, R. (2019a). As trial starts for border humanitarian volunteers, new documents reveal federal bureaucrats' obsession with stopping activists. Intercept. Retrieved from https://theintercept. com/2019/01/17/no-more-deaths-border-documents-trial/

Devereaux, R. (2019b). Bodies in the borderlands. Intercept. Retrieved from https://theintercept. com/2019/05/04/no-more-deaths-scott-warren-migrants-border-arizona/

Dinsmore, A. (2016). Why do people disappear in the desert? Retrieved from https://nomoredeaths.org/ wp-conten $t$ /uploads/2016/04/NMD-Spring-2016-Newsletter.pdf

Emerson, T. (1963). Toward a general theory of the First Amendment. New York, NY: Random House. 
Emerson, T. I. (1970). The system of freedom of expression. New York, NY: Vintage Books.

Family, J. (2019). The executive power of political emergency: The travel ban. University of Missouri Kansas City Law Review, 87, 611-628.

Fan. M. D. (2008). When deterrence and death mitigation fall short: Fantasy and fetishes as gap-fillers in border regulation. Law \& Society Review, 42(4), 701-734.

Fort Lauderdale Food Not Bombs v. City of Fort Lauderdale, 901 F.3d 235 (2018).

Gaffney, C. (2015). Volunteers triple desert area where they offer lifesaving aid. Retrieved from https:// nomoredeaths.org/volunteers-triple-desert-area-where-they-offer-life-saving-aid/

Garland, D. (1990). Punishment in modern society. Chicago, IL: University of Chicago Press.

Greenberg, Z., \& Prignano, C. (2019, August 5). Despite condemnation of hate, Trump has ramped up his use of 'invasion' rhetoric in recent months, Boston Globe. Retrieved from https://www. bostonglobe.com/news/politics/2019/08/05/despite-condemnation-hate-trump-has-rampedhis-use-invasion-rhetoric-recent-months/4tDIwWiWdbYawAS7vjhAoK/story.htm]

Gulasekaram, P. (2012). Why a wall? University of California Irvine Law Review, 2, 147-191.

Gusfield, J. (1981). The culture of public problems: Drinking-driving and the symbolic order. Chicago, IL: University of Chicago Press.

Hancock, J. (2019, July 24). Kobach Border Wall Group announces event featuring Donald Trump Jr., Steve Bannon. Kansas City Star. Retrieved from https://www.kansascity.com/news/politicsgovernment/article233069892.html

Holloman ex rel. Holloman v. Harland, 370 F.3d 1252, 1270 (11th Cir. 2004).

Hurley v. Irish-Am. Gay, Leshian \& Bisexual Grp. of Boston, 515 U.S. 557, 569 (1995).

Iftikhar, A. (2019, March 17). Trump sees immigrants as invaders. White-nationalist terrorists do too. Washington Post. Retrieved from https:/www.washingtonpost.com/outlook/2019/03/17/trumpsees-immigrants-invaders-white-nationalist-terrorists-do-too/?utm_term=.eb2d19dcaee7

Ingram, P. (2019, July 2). Scott Warren to be retried on 2 migrant harboring charges. Tucson Sentinel. Retrieved from http://www.tucsonsentinel.com/local/report/070219_scott_warren_retrial/scottwarren-retried-2-migrant-harboring-charges/

Jacobs, J. (2019, April 6). U.S. says it could take 2 years to identify up to thousands of separated immigrant families. New York Times. Retrieved from https://www.nytimes.com/2019/04/06/us/ family-separation-trump-administration. html

Jansen, B., \& Gomez, A. (2018, November 26). President Trump calls caravan immigrants "stone cold criminals." Here's what we know. USA Todey. Retrieved from https://www.usatoday.com/story/ news/2018/1 1/26/president-trump-migrant-caravan-criminals/2112846002/

Kellum, N. W. (2008). Permit schemes: Under current jurisprudence, what permits are permitted? Drake Law Review, 56, 381-425.

Lindo, E., Williams, B., \& González, M-.T. (2018) Uncompromising hunger for justice: Resistance, sacrifice, and LatCrit theory. Seattle Journal for Social Justice, 16, 727-822.

Magarian, G. P. (2017). Managed speech: The Roberts court's First Amendment. New York, NY: Oxford University Press.

Maril, R. L. (2011). The fence: National security; public safety, and illegal immigration along the U.S.Mexico horder. Lubbock, TX: Texas Tech University Press.

Matalon, L. (2019, May 28). Extending 'zero tolerance' to people who help migrants along the border. National Public Radio. Retrieved from https://www.npr.org/2019/05/28/725716169/extendingzero-tolerance-to-people-who-help-migrants-along-the-border

McAdams, R. H. (2009). Jury nullification checks prosecutorial power. In P. Robinson, K. K. Ferzan, \& S. Garvey (Eds.), Criminal law conversations (pp. 551-552). New York, NY: Oxford University Press.

McDonnell, P. J. (2019, July 9). Death at the border: Four from Guatemala, three of them children, succumb to heat in Texas. Los Angeles Times. Retrieved from https://wwwlatimes.com/ world/la-fg-guatemala-migrants-20190708-story.html

McGoldrick, J. (2008). Symbolic speech: A message from mind to mind. Oklahoma Law Review, 61, 67.

McGuire, R. M., \& Van Dyke, R. M. (2019). Crossing la Linea: Bodily encounters with the U.S.Mexico border in Ambos Nogales. In T. E. Sheridan \& R. H. McGuire (Eds.), The border and its hodies (pp. 41-70). Tucson, AZ: University of Arizona Press.

Meissner, D., \& Gelatt J. (2019). Eight key U.S. immigration policy issues: State of play and unanswered questions. Migration Policy.org. Retrieved from https://www.migrationpolicy.org/sites/ default/files/publications/ImmigrationIssues2019_Final_WEB.pdf 
Morales, D. I. (2013). Immigration reform and the democratic will. University of Pennsylvania. Journal of Law and Social Change, 16, 49-93.

Morales, D. I. (2017). "Illegal" migration is speech. Indiana Law Journal, 92, 735-782.

Nathan, D., \& Rozensky, J. (2019, June 11). Private border wall expands onto federal land, blocking access to historic site. Intercept. Retrieved at https://theintercept.com/2019/06/11/privateborder-wall-federal-land/

Nat'1 Socialist Party of America v. Vill. of Skokie, 432 U.S. 43 (1977).

Nielsen, K. (2018, May 23) Remarks at a roundtable discussion on immigration. Retrieved from https:// www.whitehouse.gov/briefings-statements/remarks-president-trump-roundtable-discussionimmigration-bethpage-ny/

No More Deaths (NMD). (n.d.-a). About No More Deaths. Retrieved from http://forms.nomoredeaths.org/about-no-more-deaths/

No More Deaths (NMD). (n.d.-b). Faith-based principles for immigration reform. Retrieved from https://nomoredeaths.org/about-no-more-deaths/faith-based-principles-for-immigrationreform/

No More Deaths (NMD). (n.d.-c). Abuse documentation. Retrieved from http://forms.nomoredeaths. org/abuse-documentation/

No More Deaths (NMD). (n.d.-d) \#WaterNotWalls. Retrieved from https://nomoredeaths.org/legaldefense-campaign/waternotwalls/

No More Deaths (NMD). (2013, January 13). Border patrol harassment and vandalism. Retrieved from https://youtu.be/8MmOWHHCav4 (timestamp 6:20).

No More Deaths (NMD). (2016). Dear friends of No More Deaths. Retrieved from https:/l nomoredeaths.org/wp-content/uploads/2016/04/NMD-Spring-2016-Newsletter.pdf

No More Deaths (NMD). (2017) Dear Friends of No more Deaths. Retrieved from https:// nomoredeaths.org/wp-content/uploads/2017/04/Newsletter-2017spring-v3a-eng-export.pdf

No More Deaths (NMD). (2018). Footage of border patrol vandalism of humanitarian aid, 2010 2017. Retrieved from http://forms.nomoredeaths.org/footage-of-border-patrol-vandalism-ofhumanitarian-aid-2010-2017/

Pew Research Center. (2019). Public's priorities for U.S. asylum policy: More judges for cases, safe conditions for migrants. Retrieved from https://www.people-press.org/2019/08/12/publicspriorities-for-u-s-asylum-policy-more-judges-for-cases-safe-conditions-for-migrants/

Phillips, K. (2019, January 20). They left food and water for migrants in the desert. Now they might go to prison. Washington Post. Retrieved from https:/www.washingtonpost.com/nation/2019/01/20/ they-left-food-water-migrants-desert-now-they-might-go-prison/

Post, R. C. (2011). Participatory democracy and free speech. Virginia Law Review, 97, 477.

realDonaldTrump. (2015, June 19). Druggies, drug dealers, rapists and killers are coming across the southern border. When will the U.S. get smart and stop this travesty? [Tweet]. Retrieved from https://twitter.com/realdonaldtrump/status/612083064945180672?lang=en

Reineke, R. (2019). Necroviolence and postmortem care along the U.S.-Mexico border. In T. E. Sheridan \& R. H. McGuire (Eds.), The border and its bodies (pp. 144-172). Tucson, AZ: University of Arizona Press.

Richards, D. A. J. (1999). Free speech and the politics of identity. New York, NY: Oxford University Press.

Robinson, P. (2000). Why does the criminal law care what the layperson thinks is just? Coercive versus normative crime control. Virginia Law Review, 86, 1868-1869.

Romero, S. (2019, April 18). Militia in New Mexico detains asylum seekers at gunpoint. New York Times. Retrieved from https://www.nytimes.com/2019/04/18/us/new-mexico-militia.html

Ross, J. (2016, October 20). From Mexican rapists to bad hombres, the Trump campaign in two moments. Washington Post. Retrieved from https:/www.washingtonpost.com/news/the-fix/ wp/2016/10/20/from-mexican-rapists-to-bad-hombres-the-trump-campaign-in-two-moments/

Schacht v. United States, 398 U.S. 58, 62 (1970).

Schreckinger, B. (2019, February 5). MAGA all-stars visit border to plot private wall project. Politico. Retrieved from https://www.politico.com/story/2019/02/05/maga-border-private-wall-bannonkobach-prince-1147210

Sessions, J., III. (2018, April 6). Memorandum for federal prosecutors along the southwest border. Retrieved from https://www.justice.gov/opa/press-release/file/1049751/download 
Shiffrin, S. H. (2000). Dissent, injustice, and the meanings of America. Princeton. NJ: Princeton University Press.

Shuham, M. (2019). Mistrial for border volunteer charged with felonies for aiding migrants. Tulking Points Memo. Retrieved from https://talkingpointsmemo.com/news/scott-warren-no-moredeaths-mistrial

Smolla, R. A. (1992). Free speech in an open society. New York, NY: Vintage Books.

Song S. (2019). Immigration and democracy. New York, NY: Oxford University Press.

Spence v. Washington, 418 U.S. 405, 410-11 (1974).

Stracqualursi, V. (2018, July 3). Trump blasts movement calling to abolish ICE. CNN. Retrieved from https://www.cnn.com/videos/politics/2018/06/30/trump-tweet-ice-newday-vpx.cnn

Sunstein, C. R. (1993). Democracy and the prohlem of free speech. New York, NY: Simon \& Schuster.

Terminiello v. City of Chic'ugo, 337 U.S. 1, 4 (1949).

Texas v. Johnson, 491 U.S. 397, 420 (1989).

Trump, D. (2019a, January 4). Remarks after meeting with congressional leadership on border security. Retrieved from https://www.whitehouse.gov/briefings-statements/remarks-president-trumpmeeting-congressional-leadership-border-security/

Trump. D. (2019b, February 15). Remarks by President Trump on the national security and humanitarian crisis on our southern border. Retrieved from https://www.whitehouse.gov/briefings-statements/ remarks-president-trumpnational-security-humanitarian-crisis-southern-border/

Tusk, M. B. (2003). No-citation rules as a prior restraint on attorney speech. Columbia Law Review, $103,: 202-1235$.

United States v. O'Brien, 391 U.S. 367, 377 (1968).

US Border Patrol. (1994). Border Patrol strategic plan 1994 and beyond: National strategy. Retrieved from https://www.hsdl.org//abstract\&did $=721845$

Van Wagtendonk, A. (2019, July 27). A controversial deal between US and Guatemala could reshape the asylum process. Vox. Retrieved from https://www.vox.com/2019/7/27/89.32786/guatemalaus-third-safe-country-deal-immigration-asylum-process

Virginia v. Black, 538 U.S. 343, 347 (2003).

Walker, H. (2015, July 6). Donald Trump just released an epic statement raging about Mexican immigrants and "disease." Business Insider. Retrieved from https://www.businessinsider.com/donald-trumpsepic-statement-on-mexico-2015-7

Zick, T. (2006a). Space, place, and speech: The expressive topography. George Washington Law Review, $74,439-505$.

Zick, T. (2006b). Speech and spatial tactics. Texas Law Review, 84, 581-651.

Zick, T. (2018a). Managing dissent. Washington University Law Review, 95, 1443-1444.

Zick, T. (2018b). The dynamic free speech clause. New York, NY: Oxford University Press. 